\title{
Socio-Personal, Psychological and Communicational Attributes of the Dairy Farmers in Jabalpur District of M.P. India
}

\author{
Priti Vishwakarma, Seema Naberia* and N.K. Khare \\ Department of Extension Education, JNKVV, Jabalpur-482004, (M.P.), India \\ *Corresponding author
}

\begin{tabular}{|c|c|}
\hline & A B S T R A C T \\
\hline & \multirow{6}{*}{$\begin{array}{l}\text { The research study was undertaken in Jabalpur district of M.P. to recognize the } \\
\text { socio-personal, psychological and communicational attributes of the dairy farmers. } \\
\text { Total Eight villages of Panagar block were selected randomly by including } 120 \\
\text { dairy farmers through pre-tested structural interview schedule to constitute the } \\
\text { samples for the investigation. The study uncovered the facts that majority of the } \\
\text { dairy farmers were middle age group, belonged to other backward class, had } \\
\text { education up to high school level, lived in joint family, possess medium land } \\
\text { holdings, were engaged in dairy + agriculture and falls under medium annual } \\
\text { income group. Majority of dairy farmers were found medium in different } \\
\text { attributes viz. cosmopoliteness, use of information source, mass media use, } \\
\text { innovativeness, decision making ability and achievement motivation. It was also } \\
\text { observed that a large number of them had low risk orientation. }\end{array}$} \\
\hline Keywords & \\
\hline & \\
\hline $\begin{array}{l}\text { Communicational, } \\
\text { Dairy farmers. }\end{array}$ & \\
\hline Article Info & \\
\hline $\begin{array}{l}\text { Accepted: } \\
\text { 12 September } 2017 \\
\text { Available Online: } \\
\text { 10 November } 2017\end{array}$ & \\
\hline
\end{tabular}

\section{Introduction}

Dairy farming is not only an indispensable component of agriculture, but also the most suitable production system that has enormous potential to improve the socio economic status of the large percentage of the rural population. The share of livestock product is estimated at $21 \%$ of total Agriculture sector, India owns the largest livestock population accounting for nearly $57 \%$ of the buffalo population and $16 \%$ cattle population. India ranks first in milk production accounting for $18.5 \%$ of world population, achieving an annual output of 146.3 million tons during 2015-2016 as compared to 137.69 million tons during 2014-2015 recording a growth of $6.26 \%$ whereas, the Food and Agriculture
Organization (FAO) has reported 3.1 increase in the world Milk Production from 765 million tons in 2014 to 2015 . The per capita availability of milk in India has Increase from $176 \mathrm{gm} /$ day in 1990 to $322 \mathrm{gm} /$ day by 20152016. It is more than the world average 294 gm/day during 2014. This represents sustained growth in availability of milk and milk product for growing population (Anonymous, 2016). Government agencies and policymakers of India have emphasized the key role of dairy farming in terms of improving the socio-economic status of the rural population by reducing the problems of unemployment, hence the present work has been undertaken to know the socio-personal, 
psychological and communicational attributes of the dairy farmers.

\section{Materials and Methods}

Out of the total seven blocks of Jabalpur district, the present study was conducted purposively in Panagar block, which is having maximum population of dairy farmers. Total eight villages were selected on the basis of highest dairy farmers from the Panagar block and 120 dairy farmers were interviewed through pre-tested structural interview schedule for the investigation. The collected data were scored, classified, analyzed and presented in the form of frequency count and percentage given in table 1 .

Table.1 Distribution of respondents according to their socio-personal, psychological and communicational attributes

\begin{tabular}{|c|c|c|c|}
\hline S.No. & Attributes & Frequency & Percentage \\
\hline \multirow[t]{3}{*}{ Age } & Young (Up to 35 years) & 40 & 33.33 \\
\hline & Middle (36 to 55 years) & 55 & 45.83 \\
\hline & Old (Above 55 years) & 25 & 20.84 \\
\hline \multirow[t]{4}{*}{ Caste } & General & 30 & 25 \\
\hline & Other backward classes & 40 & 33.34 \\
\hline & Schedule castes & 25 & 20.83 \\
\hline & Schedule tribes & 25 & 20.83 \\
\hline \multirow[t]{6}{*}{ Education } & Illiterate & 0 & 0 \\
\hline & Primary education & 0 & 0 \\
\hline & Middle education & 25 & 20.84 \\
\hline & High school & 42 & 35 \\
\hline & Higher secondary & 19 & 15.83 \\
\hline & College level & 34 & 28.33 \\
\hline \multirow[t]{2}{*}{ Family type } & Nuclear family & 36 & 30 \\
\hline & Joint family & 84 & 70 \\
\hline \multirow[t]{4}{*}{ Land holding } & Marginal (Up to 1 ha.) & 34 & 28.33 \\
\hline & Small (1.01 to 2 ha.) & 35 & 29.16 \\
\hline & Medium (2.01 to 4 ha.) & 50 & 41.66 \\
\hline & Large (Above 4 ha.) & 1 & 0.85 \\
\hline \multirow[t]{3}{*}{ Occupation } & Only Dairy & 19 & 15.84 \\
\hline & Dairy + Agriculture & 78 & 65 \\
\hline & Dairy + Agricultural along with other occupation & 23 & 19.16 \\
\hline \multirow[t]{3}{*}{ Annual Income } & Low (Up to Rs $1,00,000)$ & 41 & 34.16 \\
\hline & Medium (Rs $1,00,001$ to $2,00,000)$ & 55 & 45.84 \\
\hline & High (Above Rs 2,00,000) & 24 & 20 \\
\hline \multirow[t]{3}{*}{ Cosmopoliteness } & Low & 25 & 20.83 \\
\hline & Medium & 55 & 45.84 \\
\hline & High & 40 & 33.33 \\
\hline \multirow[t]{3}{*}{ Use of source of information } & Low & 43 & 35.83 \\
\hline & Medium & 58 & 48.33 \\
\hline & High & 19 & 15.84 \\
\hline \multirow[t]{3}{*}{ Mass media use } & Low & 33 & 27.5 \\
\hline & Medium & 51 & 42.5 \\
\hline & High & 36 & 30 \\
\hline \multirow[t]{3}{*}{ Risk orientation } & Low & 50 & 41.66 \\
\hline & Medium & 38 & 31.66 \\
\hline & High & 32 & 26.68 \\
\hline \multirow[t]{3}{*}{ Innovativeness } & Low & 44 & 36.66 \\
\hline & Medium & 55 & 45.84 \\
\hline & High & 21 & 17.5 \\
\hline \multirow[t]{3}{*}{ Achievement motivation } & Low & 42 & 35 \\
\hline & Medium & 52 & 43.34 \\
\hline & High & 26 & 21.66 \\
\hline \multirow[t]{3}{*}{ Decision making ability } & Low & 24 & 20 \\
\hline & Medium & 56 & 46.66 \\
\hline & High & 40 & 33.34 \\
\hline
\end{tabular}




\section{Results and Discussion}

The study revealed that majority of the respondents was of middle age group, belonged to other backward classes and had high school level of education. This might be due to lack of educational institutions during the past time in the villages. Most of the dairy farmers lived in joint family, possessed medium size of land holding ( 2.01 to $4 \mathrm{ha}$ ), and majority of the dairy farmers were having dairy + agriculture had medium annual income group. A majority of the respondents (45.84\%) had medium cosmopoliteness, in case of use of information source maximum farmers $(48.33 \%)$ had medium use of information source and mass media use $(42.50 \%)$ this finding is in line with the findings of Ninama (2012). This may be due to irregular visits of grass root level workers and non-conduction of extension activities in the villages. The highest percentage of farmers $(41.66 \%)$ had low risk orientation and nearly forty five percent dairy farmers (45. 84\%) had medium innovativeness. The majority of the farmers $(43.34 \%)$ had medium achievement motivation and medium decision making ability $(46.66 \%)$. This finding is in conformity with the finding of Raina et al., (2016) and Patel et al., (2014).

In nut shell it can be concluded as majority of the of dairy farmers were middle aged, belonged to other backward class, had education up to high school level, lived in joint family, possess medium land holdings, were engaged in dairy + agriculture and falls under medium annual income group. Majority of dairy farmers were found medium in different attributes viz. cosmopoliteness, use of information source, mass media use, innovativeness, decision making ability and achievement motivation. It was also observed that a large number of them had low risk orientation. Socio- economic traits of dairy farmers reveal that there is an extent for further improvement in socio- economic status, which ultimately lead to development of animal husbandry.

\section{References}

Anonymous. 2016. Economic survey report. Food and Agriculture Organization. http: /www.news 18.com.

Kumar A, Sidhu DS and Singh SRK. 2002. Constraints analysis of dairy farmers in Bihar. Indian Journal of Animal Research, 36(2): 102-105.

Ninama BS. 2012. Information management behaviour in relation to dairy farming among the farmers. Unpublished M.Sc. (Ag.) Thesis of CoA Rewa (M.P.).

Patel P, Patel MM, Badodia SK and Sharma P. 2014 Entrepreneurial Behaviour of Dairy farmers. Indian Research Journal Extension Education and and mass communication channel by the farm women. Indian Journal of Extension Education, 40(1\&2): 67-70.

Raina V, Bhushan B, Bakshi P and Khajuria S. 2016. Entrepreneurial Behaviour of Dairy Farmers Journal of Animal Research, 6(5): 947-953.

\section{How to cite this article:}

Priti Vishwakarma, Seema Naberia and Khare, N.K. 2017. Socio-Personal, Psychological and Communicational Attributes of the Dairy Farmers in Jabalpur District of M.P. India Int.J.Curr.Microbiol.App.Sci. 6(11): 1542-1544. doi: https://doi.org/10.20546/ijcmas.2017.611.183 